\title{
Prioritization about food safety and food hygiene by the consumers during buying of street foods in Lucknow
}

\section{Rajendra Kumar}

Amity Business School,Amity University, Lucknow, 226028, Uttar Pradesh, (India), Email: vision.agri@,rediffmail.com

\begin{abstract}
Street food is a people health concern, multiple lines of evidence reveal that foods exposed for sale on the roadsides may become contaminated either by spoilage or pathogenic micro-organisms. The significance of food safety and hygiene of the street foods has often been ignored because it is considered part of the informal sector. In Lucknow the vendors operate from busy spots all over the city, lining streets, markets, and traffic junctions. In order of these determinants, this study was conducted in urban area of Lucknow, to know about how street food consumers themselves prioritize about food safety and food hygiene during the buying of street foods in Lucknow. The results indicate that majority consumers were of 26-45years male and they were graduates and post graduates self-employed or service men. Among these 46.67 per cent consumers had prioritized about food safety and food hygiene when they made decision for buying and consuming street food while 33.33 per cent consumers prioritize to food hygiene. Therefore, from the practical standpoint, it is needed to create awareness in order to increase awareness about food safety and food hygiene among street food consumers.
\end{abstract}

Key words: Consumer, Street food, food safety, food hygiene, Lucknow, street vendor.

Paper cited: Kumar, R. (2017). Prioritization about food safety and food hygiene by the consumers during buying of street foods in Lucknow. South Asian Journal of Food Technology and Environment, 3(2): 545-553.

\section{Introduction}

The street food sector has expanded rapidly in urban areas of low and middle income societies from last a few decades, both in terms of providing access to a diversity of inexpensive foods for low income households and in offering job opportunities for many urban residents and its expansion is linked with urbanization and the need of urban populations for both employment and food (Maxwell et al., 2000).

The FAO (2010) pointed out that ruralurban migration gave a sound footing to the activities of the street food industry because of the convenience and the variety it offers. Street Foods are quick snacks, lunch or ready-to-eat foods and beverages commonly sold at display counters, refreshment parlors or at vending stalls by street food vendors and hawkers who are either stationary or ambulatory. Street foods are defined by the Food and Agricultural Organization (FAO, 1997) as ready to-eat foods and beverages prepared and sold by vendors and hawkers in streets and other similar public places .

The street food is a people health concern, multiple lines of evidence reveal that foods exposed for sale on the roadsides may become contaminated either by spoilage or pathogenic micro-organisms (Bryan, et al., 1992; Ashenafi, 1995; WHO, 1984). FAO (1997) further stipulates that street foods raise concern with respect to their potential for serious food poisoning outbreaks.

In Lucknow the vendors operate from busy spots all over the city, lining streets, markets, and traffic junctions. However, very little is known about how street food consumers themselves prioritize about food safety of food hygiene in Lucknow. Considering this fact, in 
present study, there was, an attempt has been made to explore "Prioritization about food safety and food hygiene by the consumers during buying of street food in Lucknow".

The street foods are ready-to-eat foods and beverages prepared and/or sold by vendors, especially on streets and other public places (Muleta and Ashenafi 2001). Among the factors which seem to determine how numerous and diverse street foods are in this or that country, one is clearly climate - a temperate or warm climate makes these operations much easier and also produces a larger number of passers-by who are not intent on getting to somewhere out of the cold. Another factor is the degree of economic development.

The general public might consider safe food as associated with zero risk (no risk at all). The food manufacturer, on the other hand, would consider food safe, if it is within the parameters of acceptable risk. Nevertheless, the risks of food poisoning should be reduced during food manufacture to "unacceptable risk". Consumer confidence in the safety and quality of the food supply is an important requirement and consumers are demanding protection for the whole food supply chain from primary producer to the end consumer, often described as from farm or pond to the plate approach.

Food safety is related to the prevention and elimination of food safety hazards and it is defined as the "concept that food will not cause harm to the consumer when it is prepared and/or eaten according to its intended use." In order to process and handle food safely, the foremost and most fundamental consideration must be food hygiene. "Food hygiene" refers to all conditions and measures necessary for the safety and suitability of food at all stages of the food supply chain.

Urbanization and population growth are expected to continue and street-vended foods, which are largely but not exclusively an urban phenomenon, will expand accordingly (Atkinson, 1992).

The activities comprising the informal sector are marked by a number of characteristics: ease of entry, reliance on indigenous resources, family/household ownership of the enterprise, small-scale operatives, high labor intensity, use of traditional technology and skills acquired outside the formal education system, and operating in unregulated and competitive markets (Hart 1973). Kumar and Gupta (2016) stated that street food consumers who graduate and post graduate have understanding about food hygiene was better than less educated street food consumers.

\section{Materials and Methods}

The study titled "Prioritization about food safety and food hygiene by the consumers during buying of street food in Lucknow." was carried out during November 20-30, 2017. Sample used for the investigation were collected from Gomati Nagar, Indira Nagar, Aliganj, Mahanagar, Alambagh and Chauk in Lucknow urban. Thus total 60 samples of street food consumer i.e. 10 street food consumers each from the 06 locations were selected randomly and were studied separately using survey method for recording data on issues.

Research Design: In this study exploratory research approach was adopted.

Data Collection Tools: Primary data were collected by conducting a face-to-face interview using a structured close ended questionnaire and the secondary data was collected from magazines, newspapers, research papers, journals, etc.

Data Analyses: Collected data was arranged and tabulated in Excel and imported into SPSS version 12.0 (2003) for windows for analysis, including frequencies and $\%$, for all variables.

\section{Results and discussion}

The findings of "Prioritization about food safety and food hygiene by the consumers 
during buying of street food in Lucknow" have been arranged as following:

Data on demographic features i.e. age, gender, educational level and occupation of consumers to assess the ability about understanding of food safety and food hygiene of street foods were analysed and observation recorded are presented in Table -1 .

\section{Table-1: Demographic Features of Consumers}

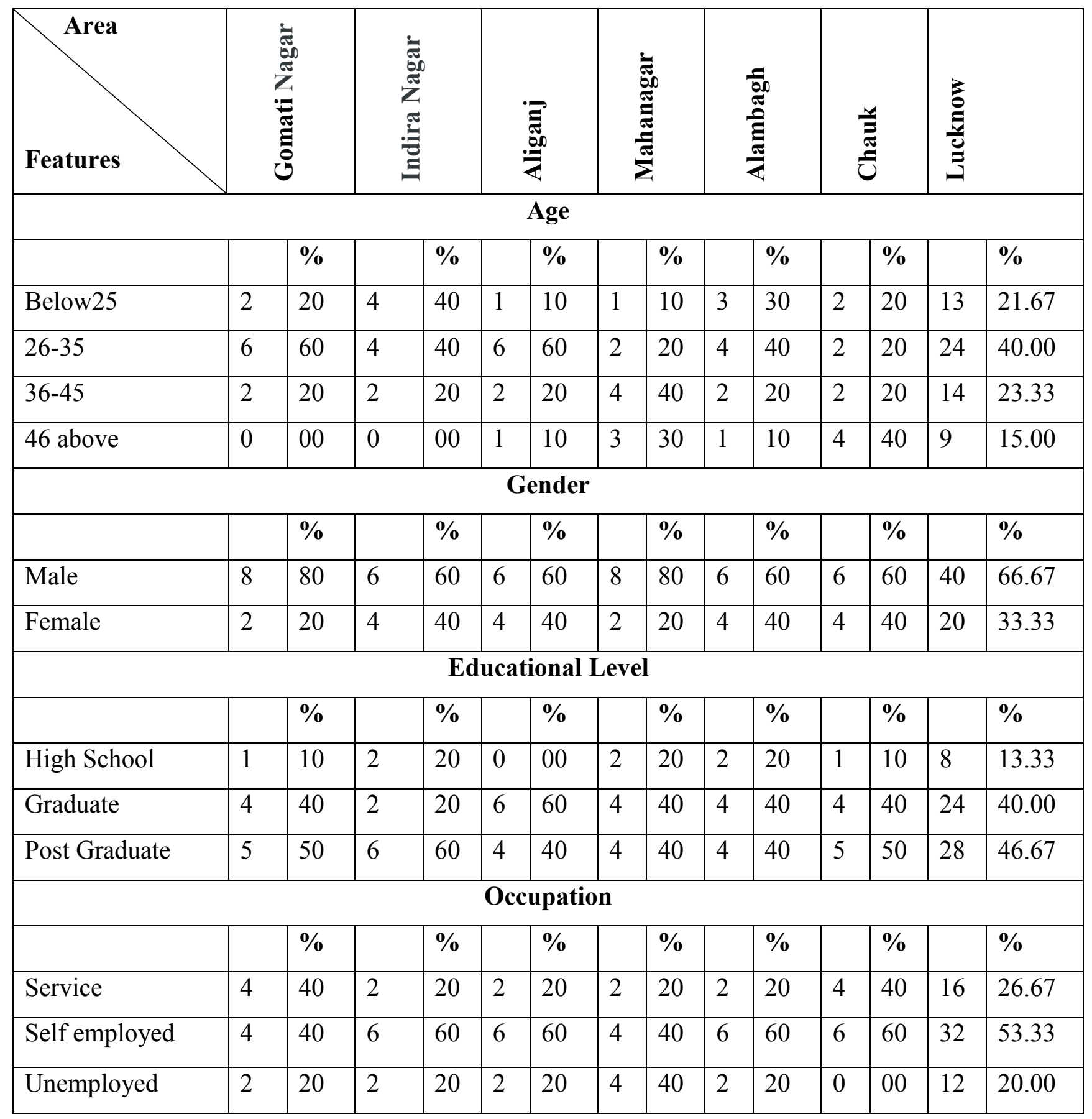




\section{Rajendra Kumar}

It is evident from above table that there was not much variability in demographic features of consumers of different location was found. Analyses of demographic features are as follows:-

Age: It was found that 40 per cent consumers of street foods belonged to age group of below 25 years in Indira Nagar followed by 30 per cent in Alambagh, 20 per cent in Gomati Nagar Chauk and 10 per cent consumers of other areas. In Gomati Nagar and Aliganj 60 per cent consumers belonged to age group of 26 to 35 years followed by 40 per cent in Indira Nagar, Alambagh and 20 per cent and in Mahanagar and Chauk. 40 per cent consumers in Mahanagar were belonging to age group between 36 to 45 years and 20 per cent consumers in remaining areas. In Chauk area, 40 per cent consumers were belonging to age group above to 46 years followed by 30 per cent consumers in Mahanagar and 10 per cent in Alambagh and Mahanagar (Fig. 1).

The consumers comprised maximum (40 per cent) from age group of 26- 35 years followed by 23.33 per cent from 36-45 years, 21.67 per cent from below 25 years and 15 per cent from above 46 years in Lucknow (Fig. 2).

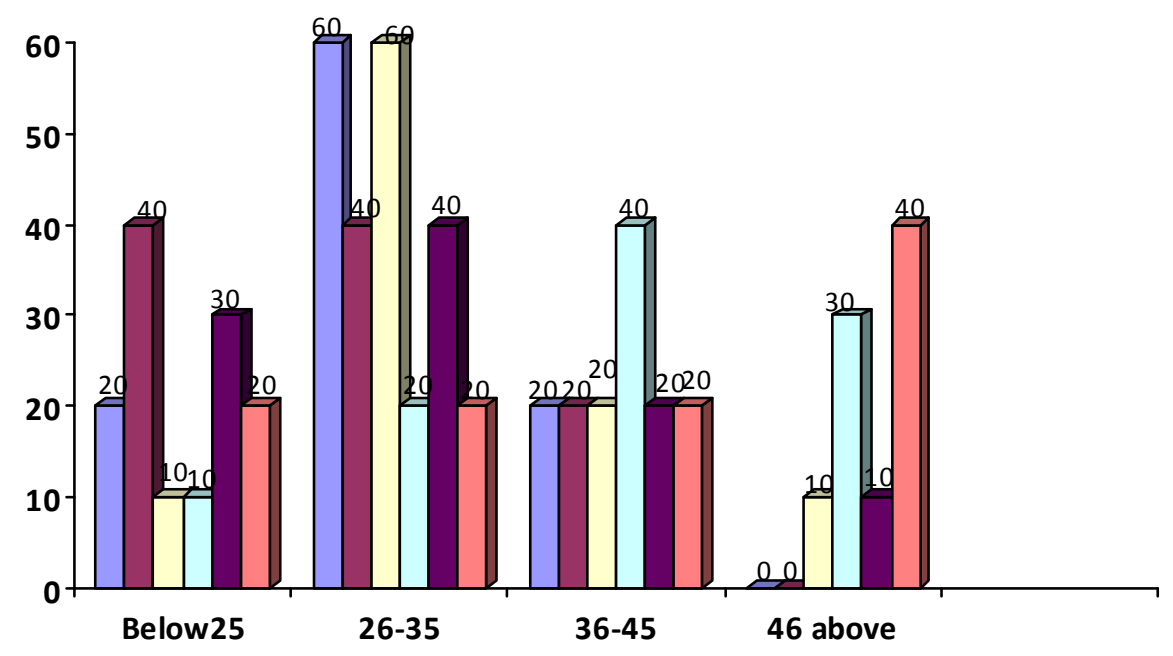

$\square$ Gomati Nagar $\square$ Indira Nagar $\square$ Aliganj $\square$ Mahanagar $\square$ Alambagh $\square$ Chauk

Fig.1: Bar diagram of consumer's age group.

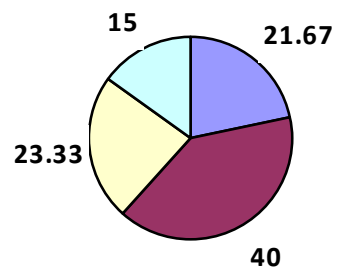

\begin{tabular}{|l|}
\hline Below25 \\
$\square 26-35$ \\
$\square 36-45$ \\
$\square 46$ above
\end{tabular}

Fig. 2: Pie diagram of consumer's age group. 
Gender: The consumers in all location have both by male and female. It is obvious from the Fig. 3 show that 60 to 80 per cent consumers belong to male category while female were only 20 to 40 per cent in all areas (Fig. 3).

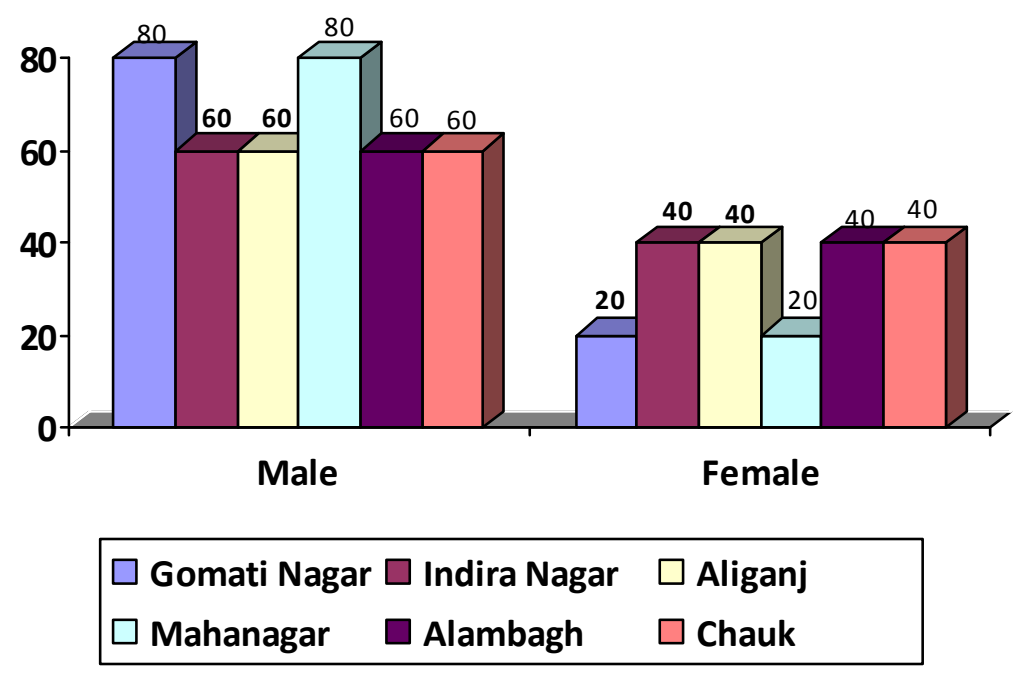

Fig. 3: Bar diagram of consumer's gender.

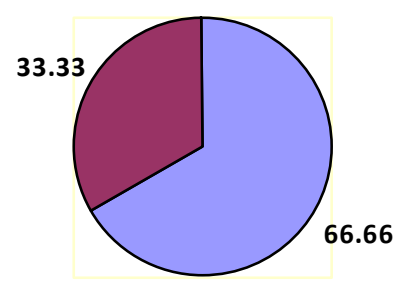

$\square$ Male
$\square$ Female

Fig. 4: Pie diagram of consumer's gender

Educational Level: The educational level varied from high school to post graduate. 60 per cent consumers were post graduate in Indira Nagar followed by 50 per cent in Gomati Nagar, Chauk and 40 per cent consumers were post graduate each in Aliganj, Mahanagar and Alambagh. Graduate consumers are highest (60 per cent) in Aliganj followed by 40 per cent in other areas except 20 per cent in Indira Nagar. Education levels of consumers were found high school highest (20 per cent) in Indira Nagar, Mahanagar, Alambagh followed by 10 per cent in Gomati Nagar (Fig. 5).

In Lucknow educational level of consumers varied from high school to post graduate. Post graduate consumers were highest (46.67 per cent) followed graduate (40 per cent) and 13.33 per cent consumers high school (Fig. $6)$. 


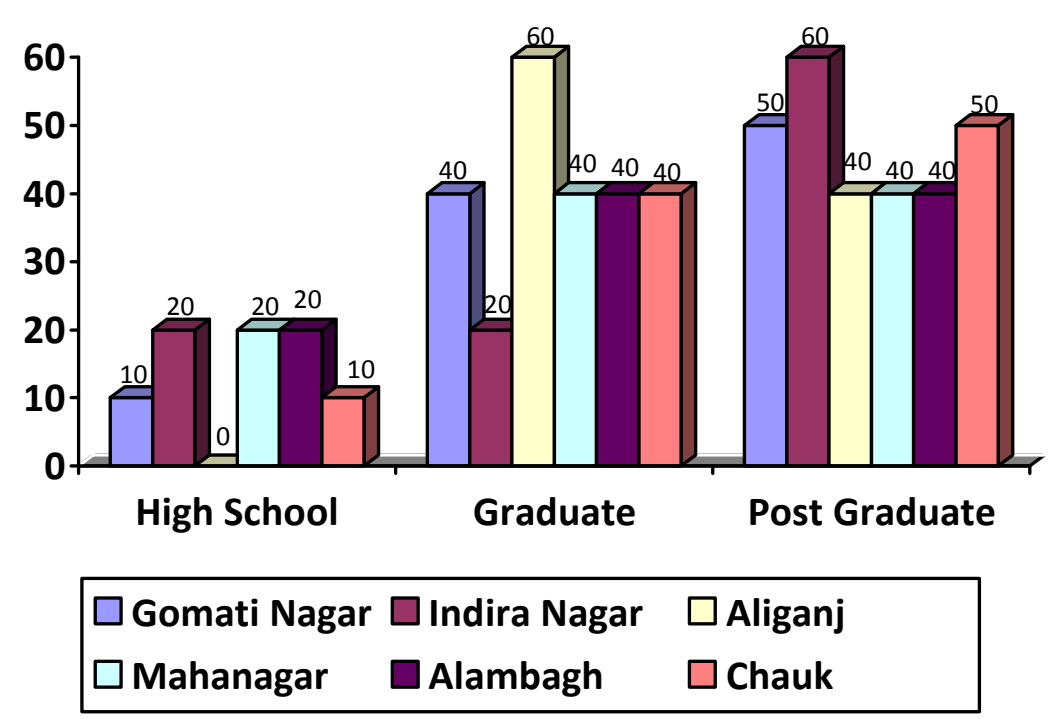

Fig. 5: Bar diagram of consumer's education levels.

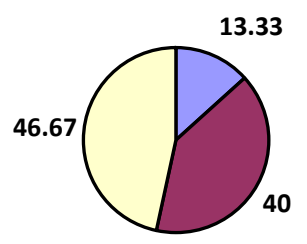

\begin{tabular}{|l|}
\hline$\square$ High School \\
$\square$ Graduate \\
$\square$ Post Graduate \\
\hline
\end{tabular}

Fig. 6: Pie diagram of consumer's education.

Occupation: The occupation of consumers varied from service, self employed and unemployed. 40 per cent consumers were service men in Gomati Nagar, Chauk followed by 20 per cent consumers of other areas. 60 per cent consumers were self employed in Indira Nagar, Aliganj, Alambagh, Chauk followed by 40 percent consumers self employed in Gomati Nagar and Mahanagar. Consumers of street food unemployed were 40 per cent in Mahanagar followed 20 per cent in remaining areas except Chauk (Fig. 7).
In Lucknow, occupation of consumers varied from service, self employed and unemployed. Maximum (53.33 per cent) consumers were self employed, while 26.67 per cent consumers were service men working with organization and 20 per cent consumers were unemployed (Fig. 8).

Data on prioritization of food safety and food hygiene issues kept in view while they were making decision to go for street foods by consumers of selected areas were analysed and observation recorded are presented in Table 2 


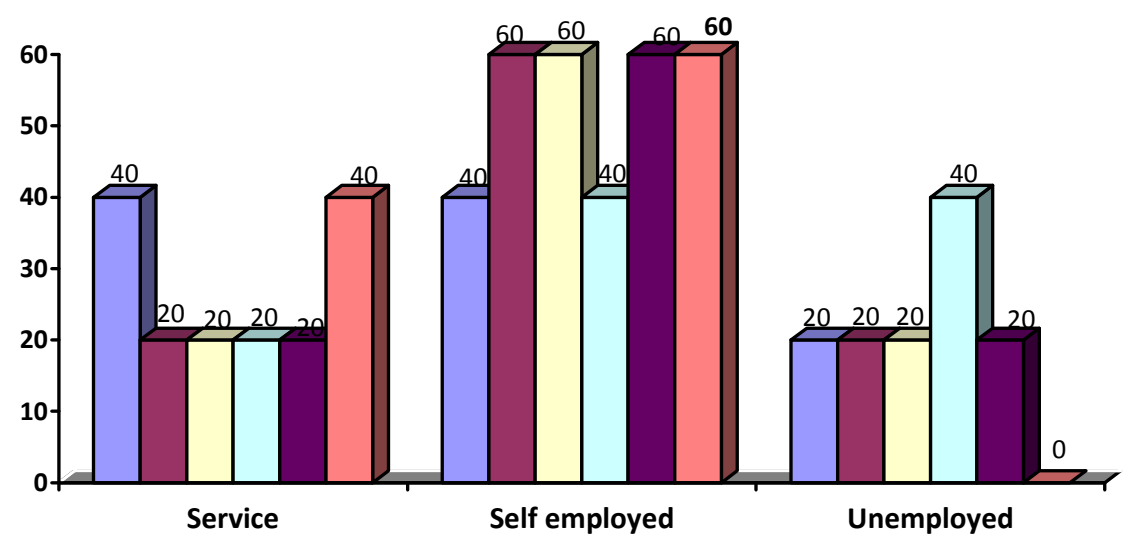

$\square$ Gomati Nagar $\square$ Indira Nagar $\square$ Aliganj $\square$ Mahanagar $\square$ Alambagh $\square$ Chauk

Fig. 7: Bar diagram of consumer's occupation.

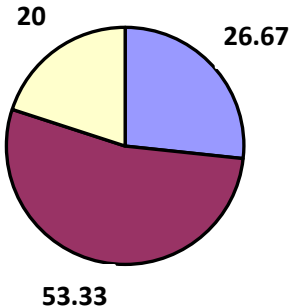

$\square$ Service
$\square$ Self employed

$\square$ Unemployed

Fig. 8: Pie diagram of consumer's occupation.

Table 2: Prioritization by consumers

\begin{tabular}{|c|c|c|c|c|c|c|c|c|c|c|c|c|c|c|}
\hline \multirow[t]{2}{*}{ Parameter } & \multicolumn{2}{|c|}{ 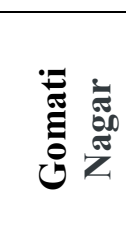 } & \multicolumn{2}{|c|}{ 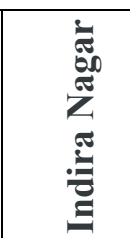 } & \multicolumn{2}{|c|}{ 㞼 } & \multicolumn{2}{|c|}{ 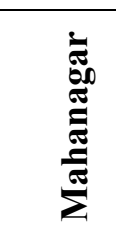 } & \multicolumn{2}{|c|}{ 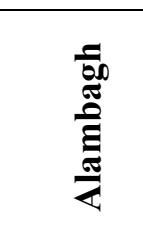 } & \multicolumn{2}{|c|}{ 节 } & \multicolumn{2}{|c|}{ 产 } \\
\hline & & $\%$ & & $\%$ & & $\%$ & & $\%$ & & $\%$ & & $\%$ & & $\%$ \\
\hline Food Safety & 1 & 10 & 1 & 10 & 1 & 10 & 2 & 20 & 2 & 20 & 3 & 30 & 10 & 16.67 \\
\hline Food Hygiene & 3 & 30 & 4 & 40 & 4 & 40 & 3 & 30 & 3 & 30 & 3 & 30 & 20 & 33.33 \\
\hline Both & 6 & 60 & 5 & 50 & 4 & 40 & 5 & 50 & 4 & 40 & 4 & 40 & 28 & 46.67 \\
\hline None of the Above & 0 & 00 & 0 & 00 & 1 & 10 & 0 & 00 & 1 & 10 & 0 & 00 & 2 & 03.33 \\
\hline
\end{tabular}

From data given in Table 2, it is evident that there was not much variability in prioritization of food safety and food hygiene issues among consumers of selected areas, findings are given below:- 
Food safety: Food safety issues were prioritized by 30 per cent consumers in Chauk followed by 20 per cent each in Mahanagar and Alambagh areas and 10 per cent in remaining area while they make decision for street foods.
Food hygiene: Food hygiene issues were prioritized by 40 per cent consumers of Indira Nagar and Aliganj followed by 30 per cent consumers of each in remaining areas.

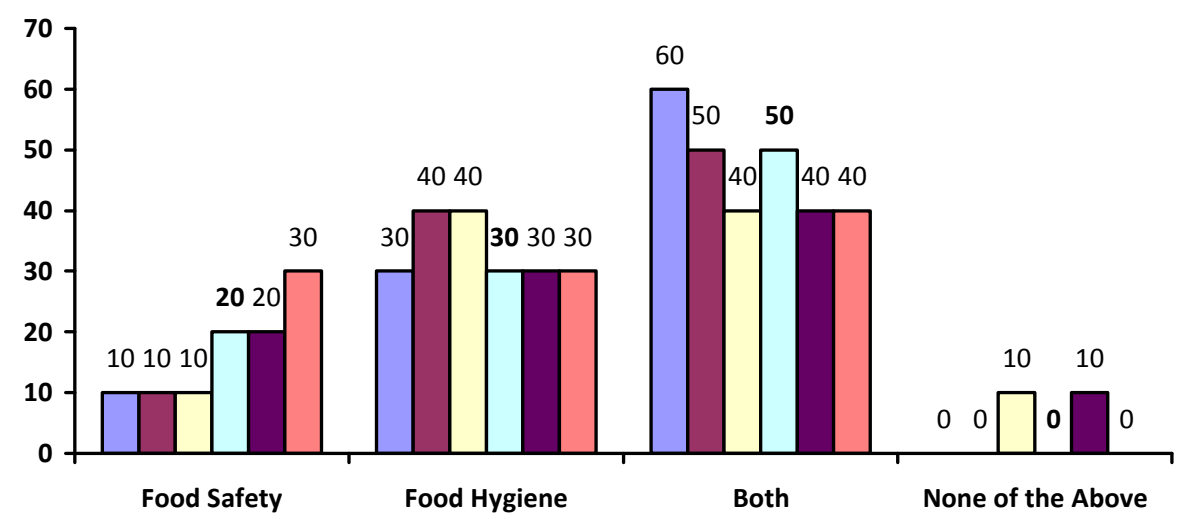

$$
\begin{array}{ll}
\square \text { Gomati Nagar } \square \text { Indira Nagar } & \square \text { Aliganj } \\
\square \text { Mahanagar } \quad \square \text { Alambagh } & \square \text { Chauk }
\end{array}
$$

Fig. 9: Bar diagram of prioritization of food safety and food hygiene issues by consumers

Food Safety and food hygiene both were prioritized by 60 per cent consumers in Gomti Nagar followed by 50 per cent consumers in Indira Nagar and Mahanagar and in remaining areas 40 per cent consumers considered both issues for prioritization while they are making decision for street food.

In Aliganj and Alambagh area 10 per cent consumers had prioritized both issues while

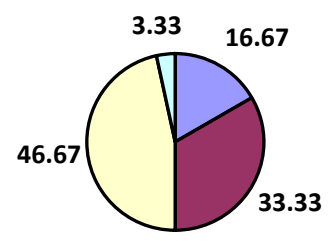

in remaining areas costumers had not given priority to food safety or food hygiene issues.

In Lucknow 46.67 per cent street food consumers were prioritizing to food safety and food hygiene while they made decision for street food followed by 33.33 per cent food hygiene, 16.67 per cent food safety where as 3.33 per cent consumers had not prioritized while they had made decision for street food.

Fig.10: Pie diagram of prioritization of food safety and food hygiene issues by consumers. 


\section{Conclusion}

Demographic data reflecting that the maximum (66.67 per cent) consumers of street food were 26-45years male, they were graduate (46.67) and post graduate (40 percent) selfemployed (53.33 per cent) or service men (26.67 per cent). Among consumers maximum (46.67 per cent) had prioritized food safety and food hygiene when they made decision for buying and consuming street food while 33.33 per cent consumers prioritize to food hygiene.

Limitations: This was a limited period study. Therefore, 12 days were a very short time to cover entire area of Lucknow.

Recommendations: It is obvious from the study that those street food consumers are graduate, post graduate and employed they had given priority on food safety and food hygiene both during the buying of street foods. Therefore, it will be pertinent and suggested that conducting a systematic and continuous campaign to generate awareness about food hygiene among street food consumers.

\section{References}

1. Ashenafi, M. (1995). Bacteriological profile and holding temperature of readyto-serve food items in an open market in Awassa, Ethiopia. Tropical and Geographical Medicine, 47: 1-4.

2. Atkinson, S.J. (1992). Food for the Cities: Urban Nutrition Policy in Developing Countries. London: London School of Hygiene and Tropical Medicine, Dept. Public Health and Policy.

3. Bryan, F. L., Teufel, P., Riaz, S., Roohi, S., Qadar, F. and Malik, Z. (1992). Hazards and critical control points of vending operations at a railway station and a bus station in Pakistan. Journal of Food Protection, 55:334-541.
4. FAO (1997). Street foods. Report of an FAO expert consultation. Jogjakarta, Indonesia, 5-9 December, 1998. FAO Nutrition Paper; 46:3-30.

5. FAO (2010). Street food: small entrepreneurs, big business. http://www.FAO/NEWS/1997/97/970408e.htm.(assessed 28 April 2010).

6. Food and Agricultural Organization (FAO). (1989). Street foods: Report of an FAO Expert Consultation Jogjakarta, Indonesia December 5-9, 1988. Food and Nutrition Paper no.46. Rome: FAO.

7. Hart, K. (1973). Informal income opportunities and urban employment in Ghana. Journal of Modern African Studies, 2(1): 61-89.

8. Kumar, R. and Gupta, R.P. (2016). Study on understanding awareness of food hygiene among street food consumers in Lucknow (Uttar Pradesh). VSRD International Journal of Technical \& NonTechnical Research, Vol. VII, Issue V, November 2016.

9. Maxwell, D., Levin, C., Armar, M., Ruel, M., Morris, S., Ahiadekeet, C. (2000). Urban livelihood and food and nutrition security in greater Accra, Ghana. International Food Policy Research Institute, Research Report 112. April 2000.

10. Muleta, D and Ashenafi, M. (2001). Salmonella, Shigella and Growth potential of other food-bourne pathogens in Ethiopian street vended foods. East African Medical Journal, 78 (11): 576580.

11. SPSS Version 12.0(2003), SPSS Web site at http://www.spss.com/worldwide

12. WHO (1984). The role of Food Safety in Health and Development: Report of a joint FAO/WHO Expert Committee on Food Safety. Technical Report Series, No. 705. 